\title{
Early Infantile Epileptic Encephalopathy 4
}

National Cancer Institute

\section{Source}

National Cancer Institute. Early Infantile Epileptic Encephalopathy 4. NCI Thesaurus. Code C162472.

An autosomal dominant form of early infantile epileptic encephalopathy, caused by mutation(s) in the STXBP1 gene, encoding syntaxin-binding protein 1. 